\title{
Kako prevoditi suvremeni francuski žargon? Traduktološka analiza hrvatskog prijevoda romana Volim sutra Faize Guene
}

\section{Abstract: How to Translate Modern French Slang? Analysis of the Croatian Translation of Faïze Guène's Novel Kiffe kiffe demain}

Just like tomorrow (Kiffe kiffe demain), a novel written by the French author Faïze Guène, was published in 2004. Shortly after its publication, the novel was translated into twenty foreign languages. The Croatian translation appeared in 2006. Kiffe kiffe demain describes a year in the life of a teenage girl of Moroccan origin, living in one of the suburbs in northern Paris. The novel is written mostly in slang. The aim of this paper is to analyse the lexical, grammatical and syntactic specifics of the language in which the novel was written, to determine the difficulties that the translator encountered in translating them, and to analyze the Croatian translation of the novel Kiffe kiffe demain. The analysis is based on close reading and comparative analysis of the original text and its translation, taking into account the linguistic, stylistic, textual, and cultural issues relevant to the translation. Comparative analysis of the original and the translation, apart from their philological, lexical, formal-stylistic, and poetic features, also encompasses the cultural aspect with reference to contemporary translation theories.

Keywords: Faïza Guène, littérature de banlieue, slang, suburbs (banlieues), translation studies, translation analysis, Just like tomorrow

\section{Na mjestu uvoda}


Kratki roman francuske spisateljice Faïze Guène pod naslovom Kiffe kiffe demain objavila je izdavačka kuća Hachette Littératures 2004. godine. Autorica romana u to je vrijeme imala svega devetnaest godina pa je stoga izniman uspjeh romana bio pomalo neočekivan[1] Tijekom prva dva mjeseca nakon objave prodano je oko 15 000, a u iduće dvije godine više od 400000 primjeraka romana (Surdot 895). Nekoliko mjeseci po objavi roman je preveden na engleski jezik, a potom i na desetke drugih stranih jezika, među kojima i na hrvatski 2006. godine.

Pripovjedačica romana u prvom licu petnaestogodišnja je Doria, djevojčica marokanskog podrijetla, rođena u Francuskoj. Radnja romana prati događaje tijekom jedne godine njenog života, od trenutka kad je otac napustio nju i njenu majku te odselio u Maroko do trenutka kad su uspjele prevladati niz teškoća koje je svakodnevni život postavio pred njih (majčina nezaposlenost, financijski problemi, nadzor socijalne službe, neuspjeh u školi itd.) i s optimizmom se okrenuti budućnosti. Doria, na jednostavan, autentičan i humorističan način, pripovijeda o svakodnevnom životu u četvrti ironično imenovanoj cité du Paradis u Livry-Garganu, jednom od predgrađa na sjeveru Pariza nastanjenom uglavnom stanovništvom imigrantskog podrijetla. Predgrađe reprezentirano u romanu Volim sutra odudara od dominantnog prikaza predgrađa francuskih gradova u medijima kao mjesta nasilja, kriminala, bezakonja, trgovine drogom, paljenja automobila itd. (Sedel; Fredette 126-50). Pripovjedačica romana problematizira vlastiti osjećaj nepripadnosti i isključenja iz dominantne francuske kulture. Njen identitet konstruira se u opreci i prema francuskom i prema marokanskom nacionalnom identitetu, a temelji se na pripadnosti mikrosvijetu predgrađa i hibridnoj globalnoj popularnoj kulturi.

Faïza Guène dio je skupine francuskih književnika imigrantskog podrijetla odraslih u predgrađima velikih francuskih gradova, koji u svojim tekstovima na različite načine obrađuju tematiku marginalizacije, nepripadanja, problematičnog identiteta i borbe s predrasudama. ${ }^{[2]}$ Izrazito zanimanje za „autore iz predgrađa“ podudara se s porastom zanimanja za problem integracije stanovništva imigrantskog podrijetla u Francuskoj, ali i u cijeloj Europi, posebice nakon posljednjih značajnijih nemira u predgrađima većih francuskih gradova krajem 2005. godine ${ }^{[3]}$ Pri pokušaju klasifikacije njihova opusa francuska je književna kritika kreirala različite etikete, koje u pravilu ukazuju na nepripadanje autora u kanon francuske književnosti, kao i na još uvijek prisutan duh kolonijalizma u francuskom društvu: la littérature maghrébine d'expression française (književnost iz 
Magreba francuskoga jezičnog izraza), la littérature française immigrée (francuska imigrantska književnost), la littérature arabo-française (arapsko-francuska književnost), la littérature de banlieue (književnost iz predgrađa), la littérature de la post-migration (književnost post-migracije) (Pinçonnat 126-50; Geiser 121-39; Durmelat; Hargreaves 144-49). Jezik kojim su tekstovi tzv. autora iz predgrađa napisani svojim se leksičkim i morfološkim posebnostima razlikuje od standardnoga francuskog jezika. Proza evocira spontani govorni jezik, stvara se iluzija usmenog pripovijedanja i izravnog obraćanja čitatelju, koristi se žargonski leksik, česte su posuđenice, posebice iz arapskog jezika, i različite glasovne redukcije, intonacijske jedinice su kraće, izostaju složene sintaktičke relacije i učestalo se koriste poštapalice i semantički prazne popune. Sociolingvistički markirana jezična obilježja u funkciji su karakterizacije likova. Primjerice, vokabular koji likovi koriste ukazuje na njihovu pripadnost određenoj društvenoj skupini (klasnoj, supkulturnoj, regionalnoj, generacijskoj). Nestandardna su jezična sredstva posebice identitetski potentna i, kao takva, ključna sastavnica stilske razine izraza.

\section{Jezična obilježja romana Kiffe kiffe demain}

Roman Faïze Guène napisan je razgovornim stilom, ili jezikom koji je nekim svojim osobinama blizak žargonu. Razgovorni jezik, kao funkcionalni stil određen neformalnom upotrebom, ima svoje zakonitosti. Simeon ga u Enciklopedijskom rječniku lingvističkih naziva definira kao: „neusiljen, prirodan, familijaran, 'srednji' stil koji se rabi u običnom govoru, a služi za potrebe svakodnevnog sporazumijevanja o tekućim životnim pitanjima“ (243-44). Ključne su mu odlike: eliptičnost, prisutnost vulgarizama, dijalektizama i provincijalizama, štedljivost na leksičkoj, fonološkoj, morfološkoj i sintaktičkoj razini, redukcija samoglasnika, česte poštapalice te slobodniji redoslijed riječi u odnosu na druge funkcionalne stilove (Silić 117). Dio informacija u razgovornom se stilu prenosi prozodijom (intonacija, ritam, jezični tempo, jačina glasa). Raslojava se prema socijalnim i geografskim kriterijima, pa tako postoje društveno, lokalno i regionalno specifične varijante kolokvijalnog jezika - žargoni, koji imaju svoje posebne značajke. Ranko Bugarski žargon definira kao: „neformalni i pretežno govorni varijetet nekog jezika koji služi za identifikaciju i komunikaciju unutar neke društveno određene grupe - po profesiji, socijalnom statusu, uzrastu i slično - čije članove povezuje zajednički interes ili način života, a koja uz to može biti i teritorijalno omeđena“ 
(12). Žargon nastaje iz potrebe članova pojedine društvene grupe da se unutar nje afirmiraju i identificiraju. To je vrsta ostvarenja kolektivnog identiteta, u opoziciji spram neutralnog i bezbojnog jezika većine. Bugarski razlikuje profesionalne, supkulturne i omladinske žargone, a sinonim za supkulturne i omladinske žargone je slang ili argot. Prema Bugarskom, obilježja su žargona leksička produktivnost i inovativnost, gramatička fleksibilnost, semantička ekspresivnost, metaforičnost i asocijativnost te humorno poigravanje zvukom i značenjem (21). Leksik, po kojem je žargon najprepoznatljiviji, obogaćuje se različitim načinima tvorbe riječi: metaforizacijom, posuđenicama, permutacijama slogova ili glasova, skraćivanjem, slaganjem, srastanjem i sufiksacijom.

Žargon kojim je napisan roman Kiffe kiffe demain razvio se u predgrađima francuskih gradova koja su nastanjena pretežno stanovništvom imigrantskog podrijetla. Francuski lingvist Jean-Pierre Goudaillier uvodi pojmove argot des cités, argot de banlieue i français contemporain des cités za označavanje spomenutog varijeteta francuskog jezika. Obilježje po kojem se ističe u odnosu na ostale žargone izrazita je prisutnost riječi i izraza iz arapskog i različitih afričkih jezika. Obilježava ga i uporaba nestandardnih jezičnih elemenata, vulgarizama te odstupanja od pojedinih gramatičkih i sintaktičkih normi. Mladi iz predgrađa jezikom koji govore afirmiraju vlastiti kolektivni identitet, koji se tvori u opoziciji prema standardnome francuskom jeziku, tj. francuskom društvu koje ga nameće u javnoj uporabi ${ }^{[4]}$ Jezik općenito ima izrazito važnu ulogu u konstrukciji identiteta jer mladi kroz jezik iskazuju pripadnost grupi, ali i vlastitu individualnost. Afirmacija identiteta mladih u odnosu na „druge“ tvori se posredstvom zajedničkog jezika, sociolekta koji se definira u svojoj napetosti prema standardu! ${ }^{[5]}$ Pojedinci koji osjećaju da žive u raskoraku s društvom kojem pripadaju jezikom kojim se služe označavaju svoju različitost.

$U$ radu se polazi od pretpostavke da je jezik književnih tekstova konstrukt, tj. da je fikcionalan te da je književno djelo artefakt izrađen od materijala (od jezika). Književno se djelo oslanja na jezik stvarnosti i u njemu otkriva aspekte koje će podvrgnuti vlastitoj literarnoj logici, dakle, koje će obraditi i preraditi, učiniti in takvim da se doimaju drastično različitima od svakodnevnog govora ili zapanjujuće sličnim (Kovačević i Badurina 133-35).

Jezik pripovjedačice i ostalih likova romana Kiffe kiffe demain važno je stilističko sredstvo te sredstvo karakterizacije likova, s obzirom na to da odražava njihov identitet i kulturu kojoj 
pripadaju. Polazeći od suvremenih sociolingvističkih pristupa složenim odnosima identiteta i jezičnih varijeteta (Androutsopoulos i Georgakopoulou; Joseph) i uzimajući u obzir činjenicu da su jezično diferencirani likovi zanimljiva prijevodna pojava, namjera je ovog rada utvrditi kakve je strategije odabrala prevoditeljica Kiffe kiffe demain na hrvatski jezik i je li uspješno prenijela obilježja žargona, koji je ključna sastavnica karakterizacije likova. Prijevod se razmatra u okviru književno-komparativnih istraživanja, s obzirom na posredničku ulogu prijevoda i prevoditelja. Evaluacija prijevoda vođena je načelima suvremene traduktologije (Translation studies). Polazi se od pretpostavke Umberta Eca da prevoditi znači „razumjeti unutarnji sustav nekog jezika i strukturu nekog teksta danog u tom jeziku, i stvoriti dvojnika tekstualnog sustava koji, s izvjesnom diskrecijom, može kod čitatelja proizvesti slične učinke, i na semantičkom i sintaktičkom, i na stilističkom, metričkom i fonosimboličkom planu, a isto tako i eventualne učinke kojima je težio izvorni tekst“ (16). Prema Ecu, važnije je da prijevod proizvede isti učinak kao izvornik nego da bude doslovan (69). Sličnog je stava i Henri Meschonnic koji ističe da treba prevoditi diskurs i ritam, a ne riječi, rečenice, jezik ili sadržaj $(12,95)$. Meschonnic drži da prijevod trebaju diktirati učinci koje izvorno djelo proizvodi, dakle, prijevod mora činiti ono što čini izvorni tekst (23). Pri prevođenju teksta treba tragati za ekvivalentom diskursa, ne zanemarujući pritom ni zvuk ni markirane segmente jezičnog izraza (Meschonnic 56). Rečenice u prijevodu moraju zadržati funkciju te proizvesti ekvivalentan učinak izvornog teksta. Dobar prijevod ne prevodi jezik, već diskurs pojedinog jezika (Meschonnic 152).

Uputno je osvrnuti se na hrvatski prijevod romana Kiffe kiffe demain jer je on, uz Chimoov roman Lila dit ça (Lila to kaže) ${ }_{,}^{[6]}$ jedini tekst iz korpusa tzv. književnosti iz predgrađa (littérature de banlieue) koji je preveden na hrvatski jezik. Prijevod romana Faïze Guène nije popraćen ekstenzivnim bilješkama o piscu, ili predgovorom ili pogovorom koji bi neupućenim čitateljima ponudili osnovne informacije o autorici, tekstu i kontekstu u kojem je napisan.

\section{Prijevodni izazovi romana Faïze Guène}

\subsection{Prijevod višejezičnog naslova i jezične igre}


Prevoditelji romana Kiffe kiffe demain susreću se s nizom lakših ili težih izazova. Prvi među njima je prijevod višejezičnog naslova i igre koja se tvori dvosmislenostima izvedenica riječi kif. Arapska riječ kif označava mješavinu duhana i hašiša, a kif-kif - uvijek isto, sve po starom. Udvajanjem fonema „f“ i dodavanjem fonema "e“ tvori se neologizam kiffe kiffe i glagol kiffer sa značenjem voljeti, cijeniti, uživati, biti lud za nečim. Riječ kif udvajanjem fonema „f“ i dodavanjem fonema „e“ postaje imperativ u drugom licu jednine glagola kiffer, a ponavljanjem imperativa tvori se neologizam i igra riječima sa značenjem „voli voli“.

Naslov romana odražava hibridnost jezika romana, kao i optimističan pogled pripovjedačice na budućnost pa je stoga njegov prijevod poseban izazov. Strategija prevođenja naslova može ukazati na stav i strategije koje se koriste u ostatku prijevoda. Britanski prijevod naslova (Just like tomorrow, 2006, The Random House Group, London), kao i španjolski (Manãna será otro día, 2006, Salamandra, Barcelona), dokidaju jezični pluralitet naslova, dok njegovi prijevodi na američki engleski (Kiffe kiffe tomorrow, 2006, Harcourt, New York) i talijanski jezik (Kif kif domani, 2005, Mondadori, Milano) čuvaju lingvističku heterogenost, čime ujedno ukazuju na igru riječima koja se u tekstu tvori pojmovima kif-kif i kiffe kiffe. Višejezičnost naslova poželjno je prevesti stoga što se u protivnom mijenja estetika teksta i neutraliziraju politički i kulturni aspekti diskursa pripovjedačice. Hrvatski prijevod naslova romana, Volim sutra, u potpunosti dokida heterojezičnost, no u prijevodu teksta uspješno je prenesena dvoznačnost homofona kif-kif i kiffe kiffe iz izvornika, kao što ukazuju sljedeći primjeri:

Au moins, il se passe des choses dans sa vie. Alors que pour moi c'est kif-kif demain. (76) U njegovom se životu barem nešto događa, a kod mene će sutra opet biti isto. (54)

Elle kiffe Bertrand Delanoë depuis... (163-64)

Sviđa joj se Bertrand Delanoë otkad... (115)

Maintenant, kif-kif demain je l'écrirais différemment. Ça serait kiffe kiffe demain, du verbe kiffer.

Sad bih to rekla drugačije. Rekla bih: volim sutra. Wow. (129) 


\subsection{Prijevod kulturnih specifičnosti}

Jedan od idućih izazova s kojima se prevoditelji susreću prijevod je različitih kulturnih specifičnosti iz izvorne kulture, koje mogu biti nepoznate primateljskoj publici i koje često nemaju ekvivalente u primateljskoj kulturi. Suočen s izazovom takve vrste prevoditelj na raspolaganju ima nekoliko izbora: posuđivanje ili preuzimanje, doslovan prijevod ili kalk, kulturni ekvivalent ili zamjena, objašnjenje, dodavanje, izostavljanje, neologizam te kombinacija dvaju ili više postupaka ${ }^{[7]}$ Prevoditeljica Kiffe kiffe demain na hrvatski jezik koristila je različite strategije pri prevođenju kulturnih specifičnosti, najčešće opisni prijevod te supstituciju kulturnim ekvivalentom. Učestalo se koristila fusnotama u kojima je ponudila pojašnjenja pojedinih kulturnih specifičnosti, primjerice: Tati (40), Cluedo (44), Union pour le mouvement populaire (46), velečasni Pierre (51), Galerie Lafayette (79), FNAC (86) itd. Takav postupak nije sustavno koristila s obzirom na to da značenje pojedinih kulturnih specifičnosti (stripa Tintinove avanture, lanca restorana brze prehrane Quick, toponima iz okolice Pariza Trappes i Mantes la Jolie itd.) nije objašnjeno u fusnotama. Potom, pribjegava opisnom prijevodu (le minuscule F2 preveden je kao minijaturni dvosobni stan (15), H.L. M. kao stambeni blokovi, tj. zgrade za socijalno ugrožene $(33,49)$, zone pavillonnaire kao zona s obiteljskim kućama (62), l'agent de la RATP kao kontrolor pariške službe javnog prometa (106), a RER kao prigradska podzemna željeznica (87)), supstituciji kulturnim ekvivalentom (le secours populaire u prijevodu postaje Crveni križ (19), les coupons de la CAF socijalna pomoć (19), a CAP coiffure srednja frizerska), generalizaciji hiperonimom (Parapoux je preveden kao šampon protiv ušiju (9)) te dodavanju pojma koji pojašnjava značenje riječi (Ça se passe pas comme à Carrefour (10)/ To ne ide kao u velikim trgovačkim centrima tipa Carrefour (9), Le sujet ressemblait à un titre de reportage d'“Envoyé spécial“ (97)/Tema je podsjećala na naslov reportaže iz informativne emisije Specijalni dopisnik (69)). Nešto je teži zadatak prijevod pojma la cité, značenja četvrt ili kvart. Prevoditeljica se najčešće odlučuje za pojam „naselje“ $(37,57,69,116)$, no la cité prevodi i kao predgrađe (69) stoga što se pojam la cité odnosi na četvrt s velikim stambenim blokovima s jeftinim stanovima koja se nalazi u predgrađima (les banlieues) pa i u francuskom jeziku nerijetko dolazi do semantičkog klizanja i preklapanja značenja pojmova la cité i la banlieue (Vidi: Boyer). 


\subsection{Prijevod žargonskog leksika}

Sastavni dio diskursa pripovjedačice romana Kiffe kiffe demain brojni su žargonski izrazi starijeg podrijetla koji su postali dio razgovornog jezika (npr. piquer, avoir la flemme, bosser, crever, bouffer, un mec, un gars, un gamin, un môme, un gosse, le fric, la thune, merde, un flic, un truc, une copine, une bagnole, un bouquin, une saloperie, un boulot, une nana, des sous itd.), i onog suvremenijeg te društveno i zemljopisno obilježenoga. Uobičajene prevoditeljske prakse pri prijevodu žargonskog leksika su: prijevod žargonom ciljnog jezika, prijevod leksikom standarda i kompenzacija. Prevoditeljica Kiffe kiffe demain na hrvatski jezik riječi iz žargona najčešće prevodi riječima iz žargona, na primjer: piquer sa zdipiti (12), se casser sa zdimiti (13), gaffer sa zabrljati (13), la gonzasse s treba (120), une nana s cura (92) ili mačka (120), les gosses s klinci (20), la meuf sa ženska $(13,120)$, a merde sa sranje ili usrano $(14,45,47)$. Značenje pojedinih vulgarizama u prijevodu blago ublažava: npr. les poufiasses prevodi kao „fifice“ (51) ${ }^{[8]}$ Ne koristi leksičko bogatstvo hrvatskog žargona pri prijevodu pojedinih riječi, primjerice, i des sous i le fric prevodi s lova $(75,87)^{[9]}$ a les keufs i les flics prevodi pojmom murjaci $(116){ }^{[10]}$ Pojedine francuske žargonizme na hrvatski jezik prevodi anglicizmima (la copine s frendica, a les pétards s džoint $)^{[11]}$ ili riječima iz standardnoga hrvatskog jezika (le bouquin je prevedeno kao knjiga (40), le boulot kao posao $(64,69),{ }^{[12]}$ la baraque kao kuća $(75),{ }^{[13]}$ les pompes kao cipele $(129),{ }^{[14]}$ iako u hrvatskom žargonu postoje prijevodni ekvivalenti.

\subsection{Prijevod posuđenica iz drugih jezika}

a) Posuđenice iz arapskog jezika

U diskursu pripovjedačice česti su pojmovi i izrazi arapskog podrijetla, primjerice le cheik, le ramadan, le chétane, le mektoub, le flouse, l'aïd, la hchouma, les négafas, le haâlouf, la jdida, le harki, le toubib, la babouche, le maboul, inchallah, beslama, halal, kif-kif, se faire marabouter, čija uporaba ukazuje na uporabu jezika u svrhu konstrukcije identiteta. Prebacivanje leksema iz jednog jezika u okvir drugog jezika stilistički je obilježeno. Prevoditeljica na hrvatski jezik koristi posve različite strategije pri prijevodu arapskih leksema iz izvornika. Te lekseme u prijevodu, u pravilu, 
naglašava kurzivom, dok on u izvorniku izostaje. U glavnini primjera koristi tri različite strategije. Prva je zadržavanje arapske riječi u prijevodu, uz pojašnjenje značenja u fusnoti:

Un orchestre de vieux cheikhs avec leurs tambours en peau de chameau viendra spécialement pour l'occasion. (10)

Orkestar starih cheikha sa svojim bubnjevima od devine kože doći će specijalno za tu priliku. (10)

Elle voulait que sa fille soit la plus belle à l'occasion de „L'école neuf, la jdida... Hamchoullah!“

Htjela je da njena kći za tu prigodu bude najljepša: „Nova škola, jdida... Hamchoullah!“ (109)

Druga je strategija zadržavanje arapske riječi, njeno isticanje kurzivom, a pojašnjenje u fusnoti izostaje jer se iz konteksta (prethodnih ili sljedećih rečenica) može shvatiti značenje pojma:

Chez nous, on appelle ça le mektoub. (19)

Kod nas se to zove mektoub. (14)

En plus, y aura toute la cité au mariage d'Aziz et si Maman fait ça, c'est la honte. La "hchouma“.

Osim toga, čitavo će naselje biti na Azizovu vjenčanju, pa će, ako mama to učini, puknuti bruka. Hchouma. (77)

Treća korištena strategija za prevođenje posuđenica iz arapskog jezika njihova je eliminacija i zamjena pojmom iz hrvatskog jezika:

Quand elle était jeune, une de ses voisines s'était fait marabouter au souk ...

Kad je bila mlada, jednu od njenih susjeda su urekli na tržnici ... (39)

Dans le RER, les gens regardaient ma tache et j'avais la hchouma. (124)

Bilo mi je da propadnem u zemlju od stida. (88) 
Moi je collectionne les prospectus de marabouts. (56)

Ja skupljam oglase vještica. (39)

b) Posuđenice iz romskih i jezika subsaharske Afrike

Dominantna strategija korištena u prijevodu na hrvatski jezik zamjena je pojmova iz romskih i jezika subsaharske Afrike pojmovima iz hrvatskog jezika:

En plus le manouche, avec sa tête, il suivait chacun des mouvements de son instrument, et souriait de toutes les dents, du moins celles qui lui restaient. (29)

Ciganin bi uz to svaki pokret svog instrumenta pratio glavom i široko se smiješio pokazujući zube, barem one koji su mu preostali. (23)

J'ai aussi remarqué qu' Hamoudi a encore changé de voiture. Cette fois-ci c'était une Opel Vectra rouge. Exactement la même que celle que l'assistante sociale s'était fait chouraver sur le parking en bas de chez moi. (183)

Primijetila sam isto da je Hamoudi opet promijenio auto. Ovaj put bila je to crvena Opel Vectra. U dlaku ista kao ona koju su maznuli socijalnoj radnici na parkingu ispred moje zgrade. (127)

Pour les bonnes nouvelles, je suis tombée sur un reportage du journal régional de France 3 l'autre soir et qui je vois à l'écran toute pimpante avec un boubou rose ? $(172)^{15]}$

Dobra vijest je da sam neku večer u regionalnom dnevniku na trećem programu naletjela na neku reportažu i, koga vidim na ekranu, svu dotjeranu u ružičastoj afričkoj tunici? (121)

\section{c) Posuđenice iz engleskog jezika}

U žargonu kojim je napisan Kiffe kiffe demain glavni je izvor posuđenica engleski jezik. Diskurs pripovjedačice obiluje izrazima posuđenima iz engleskog jezika, uglavnom bez fonetske i morfološke prilagodbe francuskom jeziku, primjerice, sitcom, remix, made in, winner, chips, jet-set, baby-sitter, cool, deal, fashion, flipper, fan, sweat, serial killer, call me, speed dating, poster, joint, fast-food, casting... Spomenuti su izrazi sveprisutni u francuskom jeziku i u širokoj su upotrebi. 
Prijevod anglicizama lakši je prevoditeljski zadatak s obzirom da je njihova prisutnost u hrvatskom jeziku značajna (Filipović; Drljača Margić). Prevoditeljica se odlučila za dvije strategije:

Zadržavanje posuđenice iz engleskog jezika iz izvornika

Le concept Taxiphone, il est made in bled. (171)

Koncept Taxiphonea je made in rodna gruda. (121)

En tout cas, j'ai pas envie de me retourner derrière la caisse d'un fast-food. (24)

U svakom slučaju, ne želim se jednog dana naći za blagajnom nekog fast-food restorana. (16)

Dernier niveau atteint. Bonus. Vous êtes un winner . (163)

Došli ste do posljednjeg nivoa. Bonus. Vi ste winner. (116)

Zamjena anglicizama iz izvornika hrvatskim riječima

Elle travaille peut-être dans le cinéma et s'inspire des foutaises que je lui raconte pour écrire un sitcom. (72)

Možda radi na filmu i nadahnjuje se bezvezarijama koje joj ja pričam za pisanje sapunica. (49)

Quand j'ai annoncé à maman que j'allais faire du baby-sitting, ça lui a pas fait plaisir. (61) Kada sam mami priopćila da ću čuvati djecu, nije joj bilo drago. (44)

Vous avez vu, je fais comme les avocats des films américains qui, pour défendre un serial killer ...

Shvatili ste, radim isto što i odvjetnici u američkim filmovima koji, da bi obranili klijenta serijskog ubojicu... (34)

\subsection{Prijevod leksika stvorenog metaforizacijom}

Značajan dio žargonskog leksika, i u hrvatskom i u francuskom jeziku, tvori se postupkom 
metaforizacije. Prevoditeljica na hrvatski jezik u prijevodu je prenijela značenje izraza, no ne i njegov oblik.

C'est bon, elle a de la chance, on a compris, pas la peine d'en faire tout un cake. $(40)^{[16]}$ U redu, ima sreće, shvatili smo, no ne treba sad praviti od muhe slona. (30)

J'étais fière alors j'en ai profité pour flamber un peu, pour que toutes ses tronches de cake au bahut me voient partir avec la doublure d'Antonio Banderas dans Zorro, mais en un peu plus

$$
\text { balafre. }(75)^{17]}
$$

Bila sam ponosna, pa sam iskoristila priliku da se malo pravim važna, ne bi li me sve one dupeglavke iz škole vidjele kako odlazim s dvojnikom Antonija Banderasa iz Zorroa, ali s malo više ožiljaka. (53)

\subsection{Prijevod šatre}

Šatra (le verlan), ili šatrovački govor, jezična je igra koja nastaje metatezom, tj. premetanjem slogova, a svojstvena je slangu. ${ }^{[18]}$ Važna je leksička komponenta romana Kiffe kiffe demain. U tekstu romana zastupljeni su samo najčešći oblici šatre (npr. meuf, keuf, ouf, relou, chelou itd), oni koji su ušli u razgovorni jezik te koje većina govornika francuskog jezika razumije. Bez obzira na prisustvo šatrovačkog govora u hrvatskom jeziku i postojanja niza riječi stvorenih metatezom (npr. razbu/buraz, tenkre/kreten, racu/cura, panglu/glupan), od kojih se pojedine učestalo koriste (npr. žišku, derpe, itd.), prevoditeljica je u pravilu francusku šatru zamijenila pojmovima iz žargona ili standardnog jezika. Propustila je priliku da prijevod šatre riječ za riječ, tamo gdje to nije bilo moguće, kompenzira na drugim mjestima u tekstu.

Elle est perspicace comme meuf. (11)

Bistra je to ženska. (10)

S'il m'invite pas, je le balance aux keufs... (165)

Ako me ne pozove, otkucat ću ga murjacima... (116) 
Mme Burlaud vient de me proposer un truc chelou : un séjour aux sports d'hiver organisé par la municipalité. (39)

Gospođa Burlaud mi je upravo predložila nešto sumnjivo: odlazak na zimovanje koje organizira općina. (29)

C'est ça qu'est relou avec les psychologues, psychiatres, psychanalystes et tout ce qui commence par "psy". (41)

To je zeznuto s psiholozima, psihijatrima, psihoanalitičarima i svim tim što počinju na „psih“. (29)

\subsection{Prijevod riječi skraćenih na glasovnoj i morfološkoj razini}

Zbog jezične ekonomije, skraćene riječi često se pojavljuju u žargonu. Razlikuju se tri tipa skraćenih riječi: apokopa (opadanje jednog ili više glasova na kraju riječi), afereza (izostavljanje jednog ili više glasova na početku riječi) i kontrakcija (Simenon 18). U Kiffe kiffe demain skraćene riječi učestalo se pojavljuju: un prof, la sécu, une pub, un mytho, au bac, une récré, un psy, des ados, un apéro, un pédé, la géo, le foot, écolo, fluo, parano itd. U hrvatskom se jeziku u oblikovanju skraćenih riječi koriste sufiksi, najčešće na -ić (kafić, krimić, crtić, penzić, muslić itd.)! ${ }^{[19]}$ Prevoditeljica na hrvatski jezik u dijelu primjera skraćenice prevodi skraćenicama (les profs prevodi kao profaći $(19,20,33)$, a les potes kao kompići), no u dijelu primjera zanemaruje skraćenice u izvorniku te ih prevodi integralnim oblicima istoznačnih riječi u hrvatskom jeziku:

Pour les mauvaises nouvelles, il faut s'inspirer de la télé. (93).

Za loše se vijesti treba nadahnuti televizijom. $(66)^{[20]}$

II jouait le type compatissant mais c'était un mytho. (18)

Glumio je suosjećajnog tipa, no bio je običan folirant. (14)

Je l'imagine bien à mon âge ado dépressive et un peu maso sur les bords. (133)

Mogu si je zamisliti u svojim godinama: deprimirana tinejdžerica koja pokazuje znakove mazohizma. (92) 


\subsection{Prijevod leksika stvorenog sufiksacijom}

Leksik izvornika koji je stvoren skraćivanjem i sufiksacijom, npr. discrétos, gratos, alcoolos, connard, nullard, flemmard, crevard, blédard, pétasse, blondasse, poufiasse itd. nije sustavno preveden hrvatskim riječima stvorenim sufiksacijom? ${ }^{[21]}$

Et puis un jour, elle en a eu marre, des blagues du beau-père, du saucisson sec à l'apéro et de son mari chômeur attitré qui passait son temps enfoncé dans le canapé... (128)

Tako su joj jednog dana dozlogrdili i tastovi vicevi, i suhe kobasice uz aperitiv, i njen stalno nezaposleni muž koji je provodio vrijeme zavaljen u kauču... (89)

J'arrive au lycée Louis-Blanc nom propre du dico, et là, je me retrouve au milieu d'une trentaine de poufiasses décolorées, permanentées, et liberté, égalité, fraternité. (159).

Stižem u Srednjoškolski obrazovni centar Louis-Blanc osobno ime iz rječnika i nađem se okružena s tridesetak oblajhanih, nafrkanih fifica, živjela Sloboda, Bratstvo i Jednakost! (113)

Et lui, il arrive à la kermesse au bras d'une blondasse perchée sur des talons de trente-huit centimètres prénommée Karim. (55)

A on dođe na sajam držeći se za ruke s nekom plavojkom po imenu Karim s petama od trideset i osam centimetara. (39)

\subsection{Prijevod razgovornih poštapalica i komentara}

Razgovorne poštapalice su deleksikalizirane i desemantizirane riječi, koje su izgubile izvorno značenje, a govorniku daju vremena da razmisli o onom što će, i kako, reći! ${ }^{22]}$ Razgovorni komentari su čestice koje nisu lišene leksičkog značenja te izražavaju govornikov stav ili verbaliziraju njegovu emociju.[23] $U$ diskursu pripovjedačice, ali i ostalih likova, posebice onih tinejdžerskog uzrasta, česte su poštapalice poput: ouais, enfin, bon, au fait, alors, remarque, si ça se trouve, bon, OK, quand même ili en tout cas. Usporednim čitanjem izvornika i prijevoda uočeno 
je da je prevoditeljica sustavno prenosila razgovorne poštapalice i komentare, što potvrđuju i sljedeći primjeri:

Ouais, laisse tomber, le vide-grenier pour elles c'est les Galeries Lafayette... (111)

Aha, ma pusti je, za nju je rasprodaja starih stvari kao Galeries Lafayette... (79) ${ }^{24]}$

Enfin, je veux dire qu'avec une fille, c'est plus facile! (85)

Mislim, hoću reći da je s jednom kćerkom lakše! (58)

Ouais grave! En plus, il est grave beau! (122)

Aha, mrak! Ful je zgodan! (86)

\subsection{Prijevod nepotpunih negacija}

U francuskom se jeziku negacija tvori pomoću dva morfema: ne i pas (ili point, personne, aucun itd.). U razgovornome francuskom jeziku morfem „ne“ često se ispušta, no u pisanoj formi trebao bi biti sačuvan. Primjera nepotpune negacije u Kiffe kiffe demain ima mnogo. S obzirom da se u hrvatskom jeziku negacija ne tvori pomoću dva, već samo jednog morfema (sufiksa - ne), ovo odstupanje od standardnog jezika u razgovornom u prijevodu na hrvatski jezik nije moguće prenijeti.

Elle a pas l'habitude de tenir un stylo entre ses mains. (13)

Nije navikla držati nalivpero u ruci. (11)

Tante Zohra, c'est pas ma vraie tante mais... (33)

Teta Zohra nije mi prava tetka... (25)

Je veux pas y aller parce que j'ai pas envie d'abandonner ma mère... (39)

Ne želim ići tamo jer neću napustiti majku... (29)

\subsection{Prijevod sintaktičkih redundancija}


U razgovornome francuskom jeziku česta su pojava sintaktičke redundancije, posebice suvišno ponavljanje subjekta. U prijevodu, u pravilu, navedeno jezično obilježje izvornika izostaje jer se ne može adekvatno prenijeti na hrvatski jezik:

La semaine dernière, Mme Dutruc, l'assistante sociale de la mairie, elle est revenue à la maison.

Gospođa Odnekuda, socijalna radnica iz općine, prošlog je tjedna ponovno bila kod nas. (47)

Mme Burland, elle est vieille, elle est moche et elle sent le Parapoux. (9)

Gospođa Burland je stara, ružna i miriše na šampon protiv ušiju. (9)

Elle doit être déjà enceinte la paysanne qu'il a épousée. (10)

Seljanka kojom se oženio vjerojatno je već trudna. (10)

Le proviseur, il s'appelle M. Loiseau. (13)

Ravnatelj se preziva Loiseau. (11)

Ma mère, elle s'imaginait que la France, c'était ... (21)

Moja majka je zamišljala da Francuska ... (15)

\subsection{Prijevod izostanka impersonalnog subjekta il u izrazu il y \\ a}

U razgovornome francuskom jeziku iz izraza il y a, sa značenjem postoji, nalazi se, ima itd. često se gubi impersonalni subjekt il. U prijevodu na hrvatski jezik to jezično obilježje izvornika nije, tj. nije moglo biti preneseno:

... parce que dans les miennes, y a de l'air froid qui rentre. (30-31)

... bez rupa, jer se u moje uvlači hladan zrak. (24) 
Dans l'ascenseur, y avait de la pisse et des mollards,

Lift je bio zapišan i ispljuvan... (27)

Y avait plein de jeux pour gamins,

Bilo je puno igara za klince... (37)

\title{
3.13. Prijevod pridjeva koji se koriste kao prilozi te imenica koje se koriste kao pridjevi
}

\author{
II regardait bizarre les bibelots qui sont posent sur le meuble... \\ Začuđeno je gledao drangulije na namještaju

Pridjev bizarre u navedenoj je rečenici upotrijebljen umjesto priloga. Preveden je prilogom. Kao i u idućem primjeru grave.

Elle se souvient qu'on lui doit du flouse que dans les moments il y a grave du monde...

Sjeti se da joj dugujemo lovu jedino onda kada je sve krcato...

U idućem primjeru imenica glamour, ujedno posuđenica iz engleskog jezika, koristi se umjesto pridjeva. U prijevodu relacija izostaje.

Je suis un type glamour. (23)

Baš sam faca. (16)

\subsection{Prijevod pokazne zamjenice ça}

Pokazna zamjenica u romanu se u pravilu pojavljuje u skraćenom obliku ça, koji je zastupljeniji u govornom jeziku, umjesto u duljem obliku cela, koji se koristi u pisanom izrazu. U prijevodu se jezično obilježje gubi, kao i uloga zamjenice ça u ponavljanju subjekta. 
Ça doit bien le faire marrer, M. Schihont, d'appeler toutes les Arabes Fatma... (14)

Mora da se gospodin Schihont ludo zabavlja kada sve Arapkinje zove Fatima... (12)

Ça doit exister des Russes brunes... (107)

Zacijelo postoje smeđokose Ruskinje ... (76)

Elle m'a demandé à quoi ça me fait penser. (9)

Pitala me na što me podsjećaju. (9)

\subsection{Prijevod elizija}

U izvorniku se na mnogo mjesta uklanja završni vokal u riječi pred početnim vokalom iduće riječi radi eufonije i olakšavanja izgovora. Na pojedinim mjestima završni se vokal briše čak i ondje gdje to nije obilježje pisanog standarda. Bez obzira na pojavnost elizije u hrvatskom jeziku, u odabranim prevedenim primjerima ona izostaje. Također, propuštena je prilika korištenja elizije prilikom kompenzacija.

...quand t'es heureux et que t'as pratiquement les larmes qui te picotent au coin des yeux. (61) ... ono koje kažeš kad to stvarno misliš, kad si sretan i kad ti oči gotovo zasuze. (44)

T'es courageuse comme nana, allez, encaisse ! (133)

Hrabra si ti cura, ajde, stisni zube! (92)

De toute façon, j'veux dire, à quoi ça sert de vivre ? (136)

Isto ti je kako god okreneš, hoću reći, čemu služi živjeti? (96)

\subsection{Prijevod francuskog jezika koji govore manjine}

Zanimljiv prijevodni primjer je onaj govora jednog od likova, trgovca Aziza, koji je arapskog podrijetla te slabo vlada francuskim jezikom. Prevoditeljica se našla pred izazovom jer najbrojnija nacionalna manjina u Hrvatskoj, ona srpska, govori jezik koji se od hrvatskoga ne razlikuje u tolikoj 
mjeri da bi došlo do gramatičkih interferencija. Prevoditeljica je stoga posegnula za domestikacijom i diskurs arapskog govornika francuskog jezika prevela diskursom albanskog govornika hrvatskog jezika, za kojeg je tipična zamjena fonema I s fonemom lj.

Parfois il parle avec son accent de bledard : Oh là là ! Si vous prounez cridit sur cridit, on est toujours pas sourtis de la berge. (77)

Ponekad gunđa na svom došljačkom naglasku. A joj mene! Ko sljaže dug na dug nikad bome na zeljena grana! (54)

L'institoutrice elle doumande à Toto. Combien ça fait douze bouteille de vin, a dou euros la pièce ? Et il répond quoi le p'tit? II répond : Trois jours madame. (77)

Učiteljica pita đaka: Koliko stoji dvanaest fljaša vina po dva ojra komad? I šta đak velji? Velji: tri dana. (54)

\section{Umjesto zaključka}

Metodom pomnog čitanja analizirani su prijevodi odabranih jezičnih aspekata romana Kiffe kiffe demain koji u najznačajnijoj mjeri doprinose karakterizaciji likova i stilističkom aspektu teksta, pa se stoga u prijevodu ne bi smjeli zanemariti. Uzmu li se u obzir sve teškoće s kojima se prevoditelj ovog teksta susreće, prijevod postaje poseban izazov. Načinjena je selektivna usporedba pojedinih reprezentativnih ulomaka izvornika i prijevoda s ciljem dobivanja odgovora na pitanja koje je odluke donijela prevoditeljica te koje strategije iznašla za postizanje adekvatnog prijevoda, jesu li aluzije i kulturne specifičnosti prilagođene novoj kulturi, jesu li adekvatno prenesena osnovna obilježja teksta (razgovorni stil i žargon), je li žargon jednako zastupljen u prijevodu i izvorniku, je li koristila kompenzaciju itd.

Prijevod romana Faïze Guène nije popraćen rječnikom nepoznatih/stranih riječi ili napomenom prevoditeljice u kojoj pojašnjava odabir određenih prijevodnih strategija. Prevoditeljica se našla pred izazovnim zadatkom s obzirom da se jezik romana razlikuje od standardnoga francuskog jezika te da su u tekstu u velikoj mjeri zastupljene različite kulturne specifičnosti, koje bi hrvatskim čitateljima mogle biti nepoznate. Prevoditeljica pribjegava opisnom prijevodu, supstituciji kulturnih 
elemenata te, izrazito često, fusnotama na dnu stranice u kojima pojašnjava značenje određenih posuđenica ili kulturnih specifičnosti. U prijevodu ima ukupno trideset fusnota[25]

Leksičke i sintaktičke razlike hrvatskog i francuskog jezika opravdavaju neke od prijevodnih gubitaka, ali ne opravdavaju neutralizaciju žargona i različitih nestandardnih jezičnih obilježja. Prevoditeljica uspješno prevodi posuđenice, žargonski leksik i razgovorne poštapalice. Izbjegava lokalno ili regionalno obilježen žargon te koristi samo riječi koje su postale sastavni dio razgovornoga hrvatskog jezika i koje su razumljive širokom krugu hrvatskih čitatelja. Zadržava ispovijedni ton romana i osjećaj izravnog obraćanja čitateljima. Izbjegava složenije sintaktičke oblike standardnoga hrvatskog jezika i u prijevodu prenosi jednostavnu sintaksu izvornika, kao i razgovorni ton cijelog teksta. Prevodi rečenicu po rečenicu, ne spajajući više kratkih rečenica izvornika u jednu dužu rečenicu u ciljnom tekstu. Sintaktičke distorzije teksta na francuskom jeziku ne uspijeva u potpunosti prenijeti u izvornik, što je posljedica manje rigidnosti hrvatske sintakse u odnosu na onu francuskog jezika.

No, u izvorniku postoji niz jezičnih obilježja (zamjena cela s ça, izostanak drugog morfema u negaciji, sintaktičke redundancije, ispuštanje impersonalnog subjekta il u izrazu il y a itd.) koja su važna obilježja diskursa pripovjedačice, ali su neprevodiva na hrvatski jezik zbog gramatičkih i sintaktičkih razlika, pa se stoga mijenja cjelokupni dojam diskursa u ciljanom jeziku. Prevoditeljica nije sustavno prevela sve aspekte izvornika (šatra, sufiksacije, glasovna kraćenja), čak i onda kad iste pojave postoje u hrvatskom jeziku. Potom, nije iskoristila mogućnosti koje nudi kompenzacija kako bi nadoknadila gubitak koji nastaje neprevodivim aspektima jezika izvornika. Kompenzirajući, u prijevod je bilo moguće unijeti neke od odlika razgovornog stila u hrvatskom jeziku: eliptičnost govora, izbjegavanje problema vezanih uz uporabu neodređenog i određenog oblika pridjeva, izbacivanje svih varijantnosti iz padežnih oblika, izjednačavanje instrumentala sredstva i instrumentala društva, uporaba zamjenice koji u obliku za živo, nekorištenje glagolskih priloga u složenim rečenicama, zamjena povratne zamjenice svoj s posvojnom moj, tvoj itd. (Silić 111-12)[26] Prijevod je, stoga, za nijansu jezično neutralniji i bliži standardu, tj. u manjoj mjeri udaljen od standarda nego što je izvornik. Diskurs pripovjedačice romana Kiffe kiffe demain ima iznimno važnu ulogu u konstrukciji njezina identiteta, iskazuje pripadnost grupi, tj. kulturi kojoj pripada, kao i njenu individualnost $\left[^{27]}\right.$ Prijevod koji je bliži standardnom jeziku od izvornika, kao ovaj na hrvatski 
jezik, ne postiže isti učinak kao izvornik, pa stoga može u značajnoj mjeri utjecati na stilistički plan i karakterizaciju likova.

\section{Bibliografija}

Androutsopoulos, Jannis K, and Alexandra Georgakopoulou. Discourse Constructions of Youth Identities. John Benjamins Publishing Company, 2003.

Avenel, Cyprien. Sociologie des quartiers sensibles. Armand Colin, 2010.

Bachmann, Christian, and Luc Basier. „Le Verlan: Argot d'école ou langue des Keums?" Mots, no. 8, 1984, pp. 169-87.

Boyer, Jean-Claude. Les banlieues en France: territoires et sociétés. Armand Colin, 2000.

Bugarski, Ranko, Žargon. Lingvistička studija. Biblioteka XX. Vek, 2006.

Doran, Meredith. „Negotiating Between Bourge and Racaille: Verlan as Youth Identity Practice in Suburban Paris“. Negotiation of Identities in Multilingual Contexts, edited by Aneta Pavlenko and Adrian Blackledge, Multilingual Matters, 2004, pp. 93-124.

Drljača Margić, Branka. „Engleski u hrvatskome: stavovi i uporaba“. Doktorski rad, Filozofski fakultet Sveučilišta u Zagrebu, 2010.

Durmelat, Sylvie. Fictions de l'intégration. Du mot beur à la politique de la mémoire. Harmattan, 2008.

Eco, Umberto. Otprilike isto. Iskustva prevođenja. Preveo Nino Raspudić, Algoritam, 2006.

Filipović, Rudolf. Anglicizmi u hrvatskom ili srpskom jeziku: porijeklo, razvoj, značenje. Školska knjiga, 1990.

Fredette, Jennifer. Constructing Muslims in France. Discourse, Public Identity, and the Politics of Citizenship. Temple University Press, 2014.

Geiser, Myriam. "La littérature beur comme écriture de la post-migration et forme de „littératuremonde“. Expressions magrébines, vol. 7, no. 1, 2008, pp. 121-39. 
Goudaillier, Jean-Pierre. „La langue des cités“. Communication et langages, no. 112, 1997, pp. 96110.

Goudaillier, Jean-Pierre. Comment tu tchatches ! Dictionnaire du français contemporain des cités. Maisonneuve et Larose, 2001.

Goudaillier, Jean-Pierre. „De l'argot traditionnel au français contemporain des cités“. La linguistique, vol. 38, no. 1, 2002, pp. 5-24.

Guène, Faïza. Kiffe kiffe demain. Hachette Littérature, 2004.

Guène, Faïza. Volim sutra. Prevela Jelena Rajak, Sysprint, 2006.

Hargreaves, Alec. „De la littérature beur à la littérature de banlieue: des écrivains en quête de reconnaissance“. Africultures : les mondes en relation, no. 97, 2014, pp. 144-49.

Joseph, John E., Language and Identity. National, Ethnic, Religious. Palgrave Macmillan, 2004.

Košćak, Nikola. „Kolokvijalni jezik u suvremenoj hrvatskoj prozi“. Doktorski rad, Filozofski fakultet, Zagreb, 2011.

Kovačević, Marina, and Lada Badurina. Raslojavanje jezične stvarnosti. Izdavački centar Rijeka, 2001.

Méla, Vivienne. "Parler Verlan: Règles et usages". Langage et société, no. 45, 1988, pp. 47-72.

Méla, Vivienne. „Le Verlan ou le langage du miroir“. Langage, no. 101, 1991, pp. 73-94.

Méla, Vivienne. „Verlan 2000“. Langue Française: Les mots des jeunes, observations et Hypothèses, no. 114, 1997, pp. 16-34.

Meschonnic, Henri. Poétique du traduire. Editions Verdier, 1997.

Mićanović, Krešimir. Hrvatski s naglaskom. Standard i jezični varijeteti. Disput, 2006.

Muhić-Dimanovski, Vesna. „Apokopa i afereza u funkciji jezične ekonomije“. Suvremena lingvistika, vol. 51-52, no. 1-2, 2001, pp. 191-202.

Pavlović, Nataša. Uvod u teorije prevođenja. Leykam international, 2015. 
Pinçonnat, Crystel. "Passé oublié, passé regagné: de l'émergence d'une génération d'héritiers".

Expressions maghrébins, vol. 7, no. 1, 2008, pp. 13-31.

Sabljak, Tomislav. Rječnik hrvatskoga žargona. Profil, 2013.

Sedel, Julie. Les médias \& la banlieue. Editions le bord de l'eau, 2009.

Silić, Josip. Funkcionalni stilovi hrvatskoga jezika. Disput, 2006.

Simenon, Rikard. Enciklopedijski rječnik lingvističkih naziva. Matica hrvatska, 1969.

Skelin Horvat, Anita. O jeziku i identitetima hrvatskih adolescenata. Srednja Europa, 2017.

Stébé, Jean-Marc. La crise des banlieues. PUF, 1999.

Trimaille, Cyril, and Billiez, Jacqueline. "Pratiques langagières de jeunes urbains: peut-on parler de "parler"?" Les français en émergence, edited by Chiara Molinari and Enrica Galazzi, Peter Lang, 2007, pp. 95-109.

Veselica Majhut, Snježana. "Cultural specificity in the translation of popular fiction from English into Croatian during the socialist and transition periods (1960-2010)." Doktorski rad, Universitat Rovira i Virgili, 2012. 
[1] Faïze Guène rođena je 1985. godine, u obitelji alžirskog podrijetla. Odrasla je u pariškim predgrađima Bobigny i Pantin. Studirala je sociologiju, snimala kratkometražne dokumentarne filmove na temu useljeništva i života u predgrađu te nakon romana prvijenca objavila romane Du rêve pour les oufs (2006), Les gens du Balto (2008), Un homme ça ne pleure pas (2014) i Millénium blues (2018).

[2] Među njima su i Rachid Djaïdani, Houda Rouane, Thomté Ryam, Karim Sarroub, Insa Sané, Rachid Santaki, Mohamed Razane itd.

[3] Pogibija Zyeda Benne i Boune Traoréa, koji su se bježeći pred policijom sakrili u transformator te preminuli od posljedica udara struje, pokrenula je 27. 10. 2005. nemire u Clichy-sous-Bois sjeverno od Pariza, koji su se tijekom idućih dana proširili po cijelom teritoriju Francuske. Tijekom tri tjedna trajanja nemira mobilizirano je 11500 policajaca, uzrokovano 250 milijuna eura štete i spaljeno oko 10000 automobila. Više u: Avenel; Stébé.

[4] Za spomenuti žargon koriste se i drugi nazivi, primjerice, „langue de keums“ (Bachmann i Basier 169-87), „parler de banlieue“ (Trimaille i Billiez 95-109). Više u: Doran 93-124.

[5] Standard ima simboličku funkciju jer funkcionira kao simbol nacionalne integracije ili prestižnost koju mu priskrbljuje uporaba u edukacijskom procesu, javnim institucijama i medijima (Mićanović $6)$.

[6] Chimo je pseudonim pod kojim je roman objavio nepoznati autor za kojeg je upitno je li odrastao u predgrađu.

[7] Navedena tipologija preuzeta je iz doktorskog rada Snježane Veselice Majhut (46-48). Jedna od mogućih i ne pokriva sve moguće izbore.

[8] Sabljakov rječnik žargona nudi sljedeće lekseme: fufa-uličarka, prostitutka, laka žena, fufica (146).

[9] Sabljakov rječnik žargona nudi sljedeće lekseme: genga, groši, keka, keš, kinta, lovuša, maslo, munita, pare, penezi, perje, škudi, žetoni (573). 
[10] Sabljakov rječnik žargona nudi sljedeće lekseme: cajac, cajkan, cajoš, drot, gumeni, kap, milač, mile, milek, mili, njuškalo, organ, pandur, plavi, prašinar, služba, tabator, žandar (595).

[11] Sabljakov rječnik žargona nudi sljedeće lekseme: burek, džojsa, đoks, đorđe, frulica, gica, mrkva, pepeljuga, pišća, rolica, truba, žika, žikilica, žiža (528).

[12] Sabljakov rječnik žargona nudi sljedeće lekseme: dril, džob, fatiga, kop, rinta, šiht, šljaka, šljakanac (597).

[13] Sabljakov rječnik žargona nudi sljedeće lekseme: bure, hiža, jazbina, kerna, kira, špilja, unđa (551).

[14] Sabljakov rječnik žargona nudi sljedeće lekseme: cipeliška, cokula, čun, gilja, giljara, giljarica, kopito, papak, plovak, škornja (515).

[15] Boubou je lepršava tunika koju nose pripadnici različitih afričkih naroda.

[16] En faire tout un cake u francuskom jeziku znači pridavati nečemu previše pažnje.

[17] Riječ cake znači kreten, imbecil, a kad se koristi zajedno s riječi tronche funkcionira kao uvreda. Bahut u žargonu označava školu.

[18] Više u: Méla 47-72; Méla 73-94; Méla 16-34; Goudaillier 96-110, Goudaillier 5-24.

[19] Vesna Muhić-Dimanovski ispitivala je procese tvorbe skraćenica u hrvatskom, francuskom, engleskom i njemačkom jeziku te došla do zaključka da se skraćenice u navedenim jezicima tvore na slične načine (191-202)

[20] Sabljakov rječnik žargona nudi sljedeće lekseme: telka, telkač, telkica, telkić, teliš, teva, tivica (629).

[21] U hrvatskom se jeziku sufiksi tvore sa -ks, -sa, -os (čoksa, džoks/džoint, alkos, cigos, narkos).

[22] Primjerice: e, i tako, jel, kakti, kao, kužiš, mislim, ne znam, onak, ono, ovak, ovo ono, tipa, znaš itd.

[23] Primjerice, ajde, dobar/dobra, zicer, fuck, fail itd.

[24] U odabranom se primjeru pojavila greška: treće lice množine osobne zamjenice (elles) prevedeno je trećim licem jednine (njoj). 
[25] Umberto Eco drži da se fusnota koristi u slučajevima kad prijevod nije moguć. Dodaje da fusnota ratificira prevoditeljev poraz (91).

[26] Razdoblje između 1999. i 2007. godine drži se zlatnim dobom suvremene hrvatske urbane proze tijekom kojeg se žargon rabi na razne kreativne način (Košćak 129). Među istaknutijim su primjerima Možeš pljunuti onoga tko bude pitao za nas, Naš čovjek na terenu i Užas i veliki troškovi Roberta Perišića, Kavice Andreja Puplina Dalibora Šimprage, Izlaz Zagreb jug i Oči Ede Popovića, Porno Borivoja Radakovića, Konstantin Bogobojazni Sime Mraovića, Metastaze Ive Balenovića itd. Navedeni korpus nudi obilje zanimljivih primjera uporabe žargona u prozi koji su mogli biti od koristi prevoditeljici pri potrazi za rješenjima uz pomoć kojih bi kompenzacijom nadoknadila gubitke pri prijevodu neprevodivih aspekata jezika izvornika.

[27] Anita Skelin Horvat istraživala je govor 600 adolescenata u Zagrebu i Splitu te dokazala da uporaba jezika i u mladih u Hrvatskoj ima važnu identitetsku ulogu, kao i u Francuskoj (O jeziku i identitetima hrvatskih adolescenata).

\section{(c) $($ i) (9)}

Creative Commons Attribution-NonCommercial-NoDerivatives 4.0 International License 